\title{
JUURNAL.RU
}

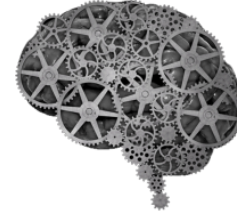

COMPANY GROUP "INTELLEKT"

\author{
Воробьев М.Ю., Пичхиде С.Я. \\ СГТУ им. Ю.А. Гагарина \\ Саратов, Россия
}

doi: 10.18411/1j2016-3-13

\section{Разработка телескопического тела позвонка для поясничного отдела}

При травмах позвоночника может происходить повреждение, как костных структур (позвонков), так и мягких тканей (межпозвонковых дисков, связок, мышц, нервных корешков, спинного мозга). Серьезными последствиями спинальной травмы является повреждение нервных структур, а также развитие нестабильности позвоночника. Нестабильность позвоночного сегмента может приводить к появлению механической боли и деформации позвоночника [1...3]. Позвонки, как и другие кости нашего организма, в норме обладают значительным запасом прочности и могут выдерживать значительные нагрузки. Однако при приложении внешней силы, превышающей прочность позвонка, происходит нарушение целостности его костной структуры, то есть происходит перелом. Перелом позвонков у лиц молодого и среднего возраста чаще возникают при воздействии очень значительной внешней силы. Протез тела позвонка предназначен для полного замещения поврежденного тела позвонка, рис.1.

Наиболее применяемый в имплантологии - это телескопический протез тела позвонка без фиксирующих пластин с пикообразными фиксирующими элементами [3].

Цель работы - достичь максимального сцепления поверхности подложки протеза со смежными позвонками и изменить конструкцию фиксирующих элементов для уменьшения травматичности при установке имплантата. 
Нами разработана конструкция межпозвоночного имплантата с пилообразными фиксаторами расположенными, в два ряда в шахматном порядке. Пилообразные фиксаторы позволяют более легко имплантировать протез в организм с наименьшими рисками повреждения смежных поверхностей здоровых позвонков. На фиксирующие подложки протеза позвонка нанесено биосовместимое керамическое покрытие Zn-гидроксиапатит. За счет этого улучшается сцепление фиксирующей подложки со смежными позвонками.

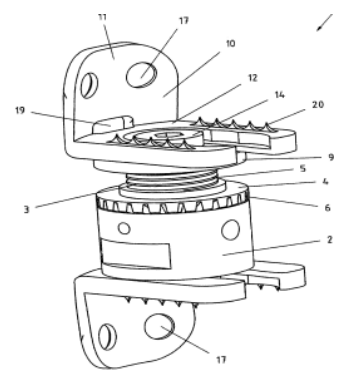

a

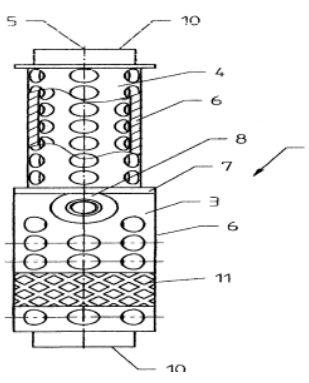

6

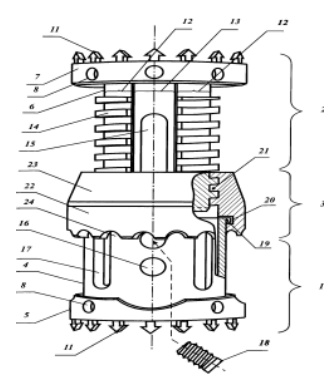

B

Рис. 1. Имплантаты - аналоги, где: а - имплантат для установки между телами позвонков позвоночника [1]; б

- межпозвонковый имплантат с эластичным конструктивным элементом [2]; в - телескопический протез тела позвонка [3]

Выводы: 1) предложена конструкция измененного фиксирующего элемента телескопического тела, позвонка который позволяет уменьшить травматичность при его установке; 2) элемент с пилообразными фиксаторами позволит улучшить сцепление протеза с поверхностью смежных позвонков.
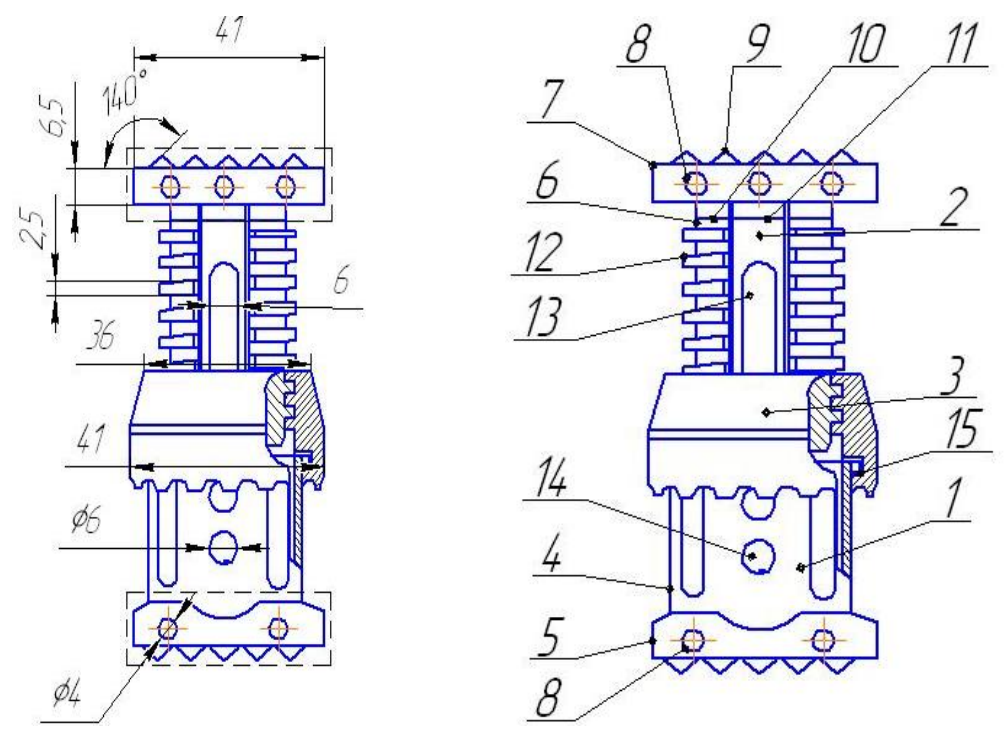

\begin{tabular}{|l|l|}
\hline Наименование & Позиция \\
\hline Нижняя часть & 1 \\
\hline Верхняя часть & 2 \\
\hline Кольцевидная муфта & 3 \\
\hline Нижнее цилиндрическое основание & 4 \\
\hline Нижняя опорная площадка & 5 \\
\hline Цилиндрическое основание & 6 \\
\hline Верхняя опорная площадка & 7 \\
\hline Отверстия & 8 \\
\hline Верхний пилообразный фиксатор & 9 \\
\hline Резьбовая секция & 10 \\
\hline Цилиндрическая секция & 11 \\
\hline Наружная резьба & 12 \\
\hline Щелевое отверстие & 13 \\
\hline Резьбовое отверстие & 14 \\
\hline Кольцевой паз & 15 \\
\hline
\end{tabular}

Рис. 2. Разработанная конструкция протеза тела позвонка 


\section{Литература:}

1. Патент РФ №2428146 от 24.10.2008. Имплантат для установки между телами позвонков позвоночника / Каст Э.

2. Патент РФ №2443400 от 16.01.2008. Межпозвонковый имплантат с эластичным конструктивным элементом / Рихтер М., Хамих С., Вилльманн $\mathrm{H}$.

3. Патент РФ №2520799 от 19.03.2013. Телескопический протез тела позвонка и способ его имплантации/Чертков А.К., Чертков А. А., Чертков К.А., Гусев Д. А. 